\title{
Lichens and allied fungi from Gauja National Park (Latvia), including new records for the country
}

\author{
Alexander Yatsyna ${ }^{1,2}$, Rolands Moisejevs ${ }^{3}$, Polina Degtjarenko ${ }^{4}$ \\ ${ }^{1}$ Belarusian State University, Biology Faculty, Nezavisimosti Ave 4, 220030, Minsk, Belarus. \\ ${ }^{2}$ V.F. Kuprevich Institute of Experimental Botany, Akademichnaya Str. 27, 220072, Minsk, Belarus. \\ E-mail: lihenologs84@mail.ru \\ ${ }^{3}$ Institute of Life Sciences and Technology, Daugavpils University, Parādes 1a, 5401, Daugavpils, Latvia. \\ E-mail: rolands.moisejevs@biology.lv \\ ${ }^{4}$ Institute of Ecology and Earth Sciences, University of Tartu, J. Liivi St. 2, 50409, Tartu, Estonia. \\ E-mail: polina.degtjarenko@ut.ee
}

\begin{abstract}
In summer and autumn 2020, a lichenological inventory took place in Gauja National Park (Latvia, Northern Europe). In total, 60 species of lichenized fungi, six non-lichenized saprophytic fungi and three non-lichenized fungi are reported as new for Gauja National Park. Among them, ten species are new to Latvia. Data on habitats, substrates, main characteristics and distribution in the neighbouring countries to Latvia are provided. The total number of lichenized and closely related fungi for Gauja National Park is 346.
\end{abstract}

Keywords: biodiversity, protected area, noteworthy findings, Baltic region, species list

\section{INTRODUCTION}

Gauja National Park (GNP or national park hereafter) is located in the north-central part of Latvia (Northern Europe), being the largest national park in the country. The national park was established in 1973 in order to protect the unique landscape of the ancient valley of river Gauja and its surroundings (Anonymous, 2021). GNP is characterized by a geologically diverse landscape which has been developed by erosion of the land surface by ancient rivers and streams (Pilāts, 2007). The total area of the national park is 91745 ha, where more than $50 \%$ is covered by forests. GNP has a high diversity of forests; boreal coniferous and mixed forests are the most common forest biotopes in the national park (Pilāts, 2007). The territory of GNP has been a part of the network of protected area Natura 2000 since 2004 (Rodríguez-Rodríguez, 2008).

The first mention of lichen collections made in the present area of GNP is known from publications by Heugel $(1854,1857,1869)$, Müller (Heugel \& Müller, 1847), Lucas (1862) and Bruttan $(1869,1870)$. In the early 20 th century extensive investigations of sandstone flora, including lichens were carried out in the GNP (Malta, 1925). The list of lichen species from the GNP was also complemented by Mereschkowski (1913). The knowledge of the lichens and allied fungi in GNP park has advanced over recent 50 years (Piterāns \& Pokule, 1975; Piterāns \& Leimane, 1987; Sundin \& Thor, 1990; Motiejūnaitè et al., 2006; Pilāts, 2007). So far, the 277 taxa of lichens and allied fungi from the GNP territory was known according to published literature data (Motiejūnaitè et al., 2006; Pilāts, 2007) and herbarium collection from the University of Latvia.

The current paper complements the list of lichenized and allied fungi from GNP, providing ten new records of lichenized and allied fungi for Latvia, and additional notes on protected and noteworthy species found in GNP.

\section{MATERIAL AND METHODS}

\section{Study area}

The climate in the GNP is attributed to Atlantic cyclones that bring air masses and precipitation from the west and northwest. The average annual temperature is $+5^{\circ} \mathrm{C}$. The coldest months are January and February, with an average air temperature of $-6^{\circ} \mathrm{C}$. The warmest month is July with an average air temperature of $+17^{\circ} \mathrm{C}$ (Pilāts, 2007; Turlājs, 2011). The study was carried out during July, August and September 2020 at 29 sites in the GNP (Fig. 1; Appendix 1). 


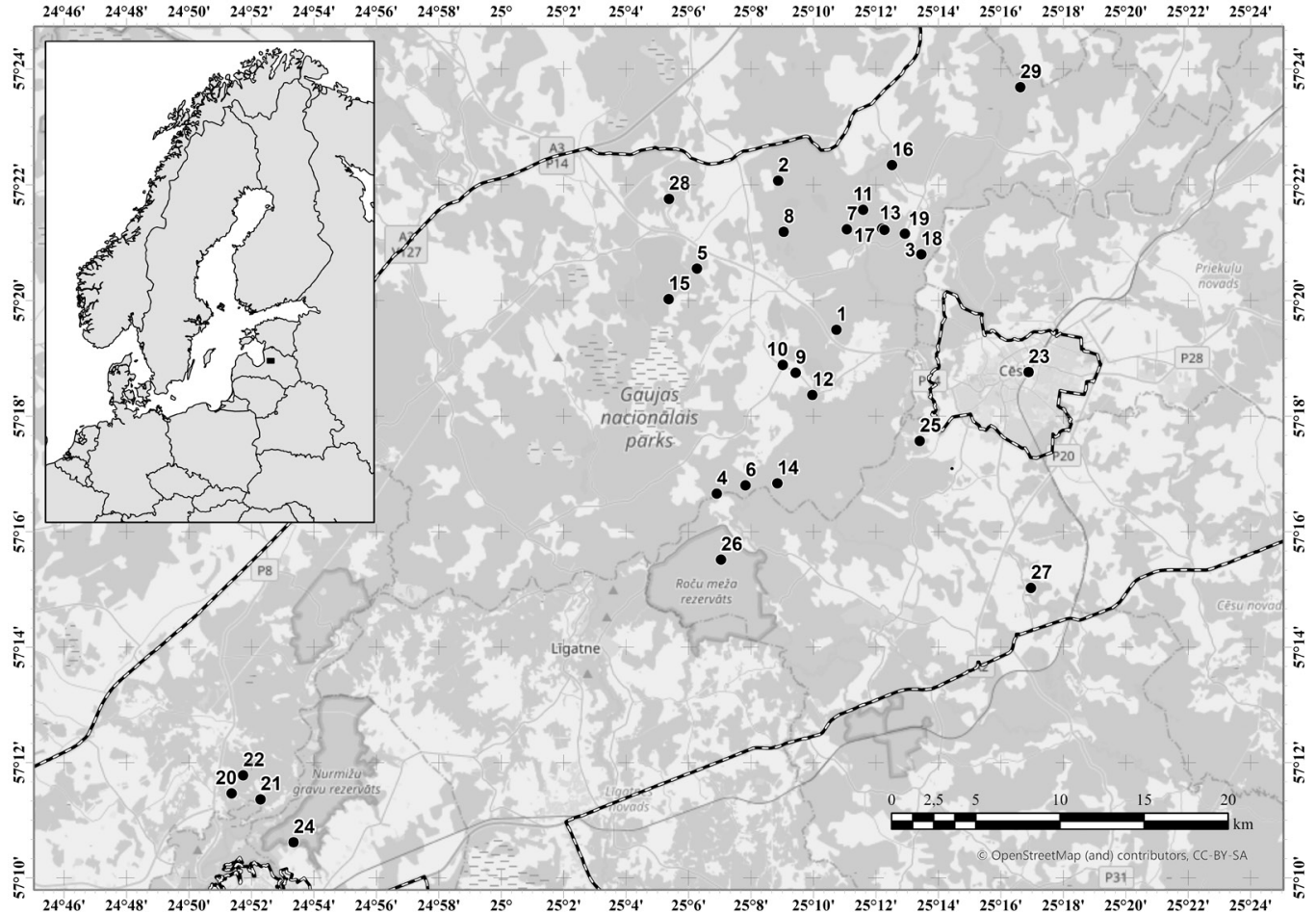

Fig. 1. Visited localities in Gauja National park (for further details see Appendix 1).

\section{Species identification}

Lichens and allied fungi were identified following routine microscopic techniques. Lichenized fungi belonging to genera Cetrelia, Cliostomum, Lepraria, Micarea, Ochrolechia, Parmelia were identified employing thin layer chromatography (TLC, solvents A \& C; Orange et al., 2001). Voucher specimens were deposited at the Herbarium of the Institute of Experimental Botany, National Academy of Sciences of Belarus, Minsk (MSK-L), the Fungarium of the University of Tartu (TUF), Estonia, and lichenological herbarium of Daugavpils University (DAU), Latvia.

\section{RESULTS \& DISCUSSION}

In total, 69 species are presented for the first time for Gauja National Park (GNP). Among them, 60 are lichenized, six saprotrophic and three non-lichenized fungi. The total number of known species of lichens and closely related fungi for the GNP is 346 species (current paper; Motiejūnaitè et al., 2006; Pilāts, 2007).
Ten species are recorded as new to Latvia: Absconditella sphagnorum, Arthonia mediella, Bacidina sulphurella, Biatora epixanthoides, Chaenothecopsis nana, Cliostomum leprosum, C. flavidulum, Fellhanera bouteillei, F. gyrophorica and Micarea tomentosa. Twelve indicator species of woodland key habitats (Motiejūnaite, et al., 2004) are recorded for the first time in the GNP: Arthonia arthonioides, Bactrospora dryina, Calicium adspersum, C. trabinellum, Cetrelia olivetorum, Chaenotheca brachypoda, Chaenothecopsis rubescens, Fellhanera gyrophorica, Microcalicium disseminatum, Opegrapha vermicellifera, Sclerophora coniophaea and $S$. farinacea. Previously, only 21 key habitat species were recorded from the national park (Pilāts, 2007). So far, 33 indicator species of woodland key habitats are currently known for the GNP.

\section{List of species}

Taxa are arranged in alphabetical order; nomenclature follows Nordin et al. (2011). The list of the recorded species includes the locality 
number and substrate type (Appendix 1). Species new to Latvia species are marked in bold; nonlichenized saprophytic fungi are marked with "+". Non lichenized, lichenicolous taxa marked with “\#”. Protected species (species included in Red Data book and Latvian legislative lists (Andrušaitis et al., 1996; Anonymous, 2000, 2013) are marked with “*”. Forest habitat codes from Annex I EU Habitat Directive, according to Latvian methodology of forest habitat identification manual, are given (Anonymous, 1992; Auniñš et al., 2013). Abbreviations of the names of collectors and determiners: AY Alexander Yatsyna, RM - Rolands Moisejevs, PD - Polina Degtjarenko.

Absconditella sphagnorum Vězda $\&$ Poelt -2 ; on dried Sphagnum spp. in the open raised bog (MSK-L 24338), leg. \& det. AY. This species forms a green-grey or olivaceous thallus on Sphagnum moss and numerous very small apothecia (Coppins, 2009). Absconditella sphagnorum was found on the sprigs of Sphagnum fuscum and S. magellanicum, in the open raised bog. Absconditella sphagnorum is known from the neighboring countries of Latvia: Lithuania (Motiejūnaitè, 2017), Estonia (Aptroot et al., 2005), and Belarus (A. Yatsyna pers. comm.).

Acarospora fuscata (Ach.) Arnold - 3; on siliceous stones (MSK-L).

ANISOMERIDIUM POLYPORI (Ellis \& Everh.) M. E. Barr 4; on trunks of Fraxinus excelsior L. (MSK-L).

*ARTHonia ARTHONioides (Ach.) A. L. Sm. - 4; on trunks of Quercus robur L. (MSK-L).

Arthonia mediella Nyl. - 5; on leaves and stems of mosses, on trunks of Quercus robur (MSK-L 24317), leg. \& det. AY. This species can be confused with $A$. arthonioides, from which it differs by smaller ascospores, being mainly 2.6-3.8 $\mu \mathrm{m}$ diam. In addition, these species are well distinguished by the shape of the photobiont. Arthonia mediella has single photobiont cells (not trentepohlioid), while A. arthonioides has loosely entwined around distinct filaments of trentepohlioid algae (Cannon et al., 2020). Distribution in the neighboring territories: Lithuania (Motiejūnaitè, 2017), Estonia (Randlane et al., 2019), Belarus (Yatsyna et al., 2019), and the European part of Russia (Pskov Oblast) (Istomina et al., 2018).
AtHallia Cerinella (Nyl.) Arup, Frödén \& Søchting6; on branches of Populus tremula L. (MSK-L).

BACIDIA FRAXINEA Lönnr. - 25; on the trunk of Fraxinus excelsior (DAU).

Bacidina SUlphurella (Samp.) M. Hauck \& V. Wirth - 7; on decaying wood of Picea abies (L.) H. Karst. (MSK-L 24309), leg. \& det. AY. This species has a thallus, apothecia and ascospores as Bacidina arnoldiana (Körb.) V. Wirth \& Vĕzda, but $B$. sulphurella clearly differs by its welldeveloped white pycnidia $0.15-0.3 \mathrm{~mm}$ diam. Bacidina sulphurella has a filiform conidia, curved or not, but always with at least one extremity strongly hooked and slightly enlarged at one end (Brand et al., 2009). This species is known in the neighboring countries: Lithuania (Motiejūnaitè, 2017), Estonia (Randlane et al., 2019) and Belarus (Yatsyna et al., 2019).

*Bactrospora dryina (Ach.) A. Massal. - 5; on trunks of Quercus robur (MSK-L).

Biatora epixanthoides (Nyl.) Diederich - 6; on trunks of Populus tremula (MSK-L 24352), leg. $\&$ det. AY. This species is commonly sterile with primarily muscicolous, grayish or yellowish green, granular verrucose thallus. Effuse soralia are often confluent and, therefore, thallus appearing leprose (Tønsberg, 1992). The collected sterile specimen was checked using TLC, but no secondary compounds were found. This species can be confused with Biatora chrysantha (Zahlbr.) Printzen, the latter contains gyrophoric acid (Tønsberg, 1992). Distribution in the neighboring territories: Lithuania (Motiejūnaitè, 2017), Estonia (Randlane et al., 2019), and Belarus (Yatsyna et al., 2019).

BiATORIDIUM MONASTERIENSE J. Lahm ex Körb. - 6; on trunks of Populus tremula (MSK-L).

Calicium abietinum Pers. - 7; on wood of Picea abies (MSK-L).

${ }^{*}$ Calicium adspersum Pers. - 6, 25; on trunks of Fraxinus excelsior and Quercus robur (MSK-L; DAU).

Calicium trabinellum (Ach.) Ach. - 8; on wood of Pinus sylvestris L. (MSK-L).

Calogaya decipiens (Arnold) Arup, Frödén \& Søchting - 9; on the rubble stones of the building (MSK-L). 
Caloplaca cerina (Hedw.) Th. Fr. - 6; on trunks of Populus tremula (MSK-L).

Caloplaca saxicola (Hoffm.) Vondrák - 9; on the rubble stones of the building (MSK-L).

Candelariella Aurella (Hoffm.) Zahlbr. - 6, 16; on trunks of Populus tremula (MSK-L).

CANDElariella efFlorescens R. C Harris \& W. R. Buck - 10, on trunks of Fraxinus excelsior (MSK-L).

Carbonicola anthracophila (Nyl.) Bendiksby \& Timdal - 29; on burned trunk of Pinus sylvestris (DAU).

${ }^{*}$ Cetrelia olivetorum (Nyl.) W. L. Culb. \& C. F. Culb. - 4; on trunks of Fraxinus excelsior (MSK-L). Secondary metabolites: atranorin, chloroatranorin, olivetoric acid.

ChAENOTHECA BRACHYPOdA (Ach.) Tibell - 11; on wood of Picea abies (MSK-L).

*Chaenotheca chlorella (Ach.) Müll. Arg - 25; on wood of Picea abies (DAU).

${ }^{*}$ Chaenotheca Gracilenta (Ach.) Mattsson \& Middelb. -25; on trunks of old Fraxinus excelsior (DAU).

*Chaenotheca phaeocephala (Turner) Th. Fr. -12 , 28; on trunks of Larix spp. and Quercus robur (MSK-L; DAU).

Chaenotheca xyloxena Nádv. - 8; on wood of Pinus sylvestris (MSK-L).

\#CHAENOTHECOPSIS EPITHALLINA Tibell - 25, 28; on thallus of Chaenotheca trichialis (Ach.) Th. Fr., growing on Quercus robur (DAU).

+Chaenothecopsis nana Tibell - 4; on trunks of Quercus robur (MSK-L 24285), leg. \& det. AY. This species has small $0.4-0.6 \mathrm{~mm}$ black apothecia, the negative reaction with $\mathrm{K}$, and the non-septate, dark, fusiform spores (Tibell, 1999). This species is known in the neighboring countries: Lithuania (Motiejūnaitè, 2017), Estonia (Randlane et al., 2019), and Belarus (Yatsyna et al., 2019).

+Chaenothecopsis Pusilla (Ach.) A. F. W. Schmidt - 8; on wood of Pinus sylvestris (MSK-L).

+CHAENOTHECOPSIS RUBESCENS Vain. - 5; on trunks of Quercus robur (MSK-L).

Cladonia CaEspiticia (Pers.) Flörke - 4; on mossy bark, at the base of the trunk of Tilia cordata Mill. (MSK-L).

*Cladonia parasitica (Hoffm.) Hoffm. - 26; on decaying wood (log) of Pinus sylvestris (DAU).

Cladonia stygia (Fr.) Ruoss - 8; among mosses and on peat in the raised bog (MSK-L).

*Cliostomum corrugatum (Ach.) Fr. - 28; on bark of Quercus robur (DAU).

Cliostomum flavidulum Hafellner \& Kalb - 24; on bark of Picea abies (TUF090824), leg. PD \& RM, det. PD. Cliostomum flavidulum is easily overlooked and similar to other yellow-green crustose sorediate species, for example Lecanora expallens, Biatora efflorescens etc. However, C. flavidulum differs by a texture of the soredia, which resembles a sulphur yellow to yellowgreen finely-sifted flour (Ekman, 1997; Simms, 2016). Prothallus is often present, thin, narrow, either whitish or bluish black. Apothecia are rare (Ekman, 1997). The examined specimen was sterile. TLC: atranorin and fumarprotocetraric acid. Distribution in the neighboring countries: Estonia (Randlane et al., 2019) and Sweden (Ekman, 1997).

Cliostomum leprosum (Räsänen) Holien \& Tønsberg - 8; on trunks of Pinus sylvestris. (MSK-L 24353), leg. \& det. AY. Cliostomum leprosum is very similar to C. corrugatum (Ach. ex Fr.) Fr., but separated from this species in having a coarse thallus that is abundantly sorediate (Tønsberg, 1992). TLC: atranorin and caperatic acid in thallus, usnic acids in apothecia. This species is found in Lithuania (Motiejūnaitè, 2017), Estonia (Randlane et al., 2019), and Belarus (Yatsyna et al., 2019).

\#Clypeococcum hypocenomycis D. Hawksw. 29; on thallus of Hypocenomyce scalaris (Ach. ex Lilj.) M. Choisy, growing on Pinus sylvestris (DAU).

${ }^{*}$ Collema flaccidum (Ach.) Ach. - 27; on granite boulders, which were part of the castle wall (DAU).

CyPHELIUM NOTARISII (Tul.) Blomb. \& Forssell - 20; on trunks of Pinus sylvestris (MSK-L).

Fellhanera bouteillei (Desm.) Vězda - 13; on twigs and needles of Picea abies (MSK-L 25009), leg. \& det. AY. This species is quite easily recognized due to its bluish sorediate thallus, 
pinkish pycnidia, white-pinkish to pale orange apothecia and distinctive habitat (Aptroot et al., 2009). Distribution in the neighboring territories: Lithuania (Motiejūnaitè, 2017), Estonia (Randlane et al., 2019), and Belarus (Yatsyna et al., 2019).

Fellhanera gyrophorica Sérus., Coppins, Diederich \& Scheid. - 4; on trunks of Quercus robur (MSK-L 24339), leg. \& det. AY. Fellhanera gyrophorica usually lacks ascomata, but is well characterized by the thallus, which is rather thick and produces pycnidia. Pycnidia are always present, sessile or slightly stalked, sometimes aggregated in clusters, pinkish to pale orange-brown, with their outer wall slightly pruinose when well-developed and typically reacting with $\mathrm{C}+\mathrm{red}$, because of production of gyrophoric acid (Sérusiaux et al., 2001). This species can be confused with other species that formed pycnidia: Fellhanera ochracea Sparrius $\&$ Aptroot and Fellhaneropsis vezdae (Coppins $\&$ P. James) Sérus. Fellhanera ochracea has typically orange-brown pycnidia and obpyriform and slightly longer (4-6 um) conidia, and $F$. vezdae has pinkish brown pycnidia, with filiform conidia, its thallus is generally thinner and smoother. Fellhanera gyrophorica is known in Lithuania (Motiejūnaitè, 2017), Estonia (Randlane et al., 2019), and Belarus (Yatsyna et al., 2019).

Hertelidea botryosa (Fr.) Printzen \& Kantvilas 11; on wood of Picea abies (MSK-L).

Hydropunctaria RHEITROPHILA (Zschacke) C. Keller, Gueidan $\&$ Thüs -1 ; on the rocks in the stream of the river (MSK-L).

HyPOGYMNIA FARINACEA Zopf - 20; on trunks of Pinus sylvestris (MSK-L).

*Inoderma Byssaceum (Weigel) Gray - 25; on bark of Quercus robur (DAU).

LEPRARIA JACKII Tønsberg - 8; on trunks of Pinus sylvestris (MSK-L). Secondary metabolites: atranorin, jackinic/rangiformic acid as main compounds, and accessories roccellic acid (minor).

LEPRARIA VOUAuXII (Hue) R. C. Harris - 4; on trunks of Fraxinus excelsior (MSK-L). Secondary metabolites: pannaric acid 6-methylester.

LOXOSPORA ELATiNa (Ach.) A. Massal. - 29; on dead wood of Picea abies (DAU).
Melanelixia subargentifera (Nyl.) O. Blanco, A. Crespo, Divakar, Essl., D. Hawksw. \& Lumbsch - 10; of Acer platanoides L. (MSK-L).

Micarea byssacea (Th. Fr.) Czarnota, GuzowKrzem. \& Coppins - 20; on trunks of Pinus sylvestris (MSK-L).

Micarea PEliocarpa (Anzi) Coppins \& R. Sant. - 8; on trunks of Pinus sylvestris (MSK-L). Secondary metabolites: gyrophoric acid.

Micarea tomentosa Czarnota \& Coppins - 4; on a rotten stump Quercus robur (MSK-L 24361), leg. $\&$ det. AY. Micarea tomentosa is characterized by a coloured thallus composed of larger granules than the goniocysts of the closely related Micarea hedlundii, which has similar, stalked, tomentose pycnidia. The dull orange pigment (reacting with $\mathrm{K}+$ violet, $\mathrm{C}+$ violet) within the goniocysts is absent, in contrast to $M$. hedlundii. The pigment inside the pycnidial walls reacts with $\mathrm{K} \pm$ violet or violet grey. In contrast to Micarea prasina, which produces micareic acid, $M$. tomentosa does not contain any substances detectable by TLC (Coppins, 1983; Czarnota, 2007). Distribution in the neighboring territories: Lithuania (Motiejūnaitè, 2017), Estonia (Randlane et al., 2019), and Belarus (Yatsyna, 2021).

+Microcalicium disseminatum (Ach.) Vain. - 4; on trunks of Quercus robur (MSK-L).

\#Muellerella hospitans Stizenb. - 27; on apothecium of Bacidia fraxinea Lönnr., growing on Fraxinus excelsior (DAU).

Multiclavula mucida (Pers.) R. H. Petersen - 4; on wood of Quercus robur, 21, on wood of Betula pendula Roth (MSK-L).

OCHROLECHIA MICROSTICTOIDES Räsänen - 8; on trunks of Pinus sylvestris (MSK-L). Secondary metabolites: thallus consists of variolaric and lichesterinic acids.

*OPEGRAPHA VERMiCELLIFERA (Kunze) J. R. Laundon4; on trunks of Fraxinus excelsior (MSK-L).

Parmelia ernstiae Feuerer \& A. Thell - 14; on trunks of Picea abies (MSK-L). Secondary metabolites: atranorin, consalazinic, salazinic, protolichesterinic, lichesterinic and lobaric acids.

PARMELIA SAXATILIS s.str. (L.) Ach. - 15; on siliceous stones (MSK-L). Secondary metabolites: atranorin, consalazinic, salazinic and lobaric acids. 
Physconia Detersa (Nyl.) Poelt - 10; on trunks of Quercus robur (MSK-L).

PHYsCONIA PERISIDIOSA (Erichsen) Moberg - 9; on trunks of Fraxinus excelsior (MSK-L).

PRotopannaria PEZIZOIDEs (Weber) P. M. Jørg. \& S. Ekman - 24; on a sandstone outcrop covered by bryophytes (DAU).

Psilolechia Clavulifera (Nyl.) Coppins - 11; on upturned roots of Picea abies (MSK-L).

Psilolechia lucida (Ach.) M. Choisy - 11; on trunks of Picea abies (MSK-L).

PYCNORA SOROPHORA (Vain.) Hafellner - 8; on trunks of Pinus sylvestris (MSK-L).

RusAVSKIA ELEGANS (Link) S. Y. Kondr. \& Kärnefelt 9; on the rubble stones of the building (MSK-L).

+SAREA DifFormis (Fr.) Fr. - 17; on the resin of Picea abies (MSK-L).

+SAREa REsinae (Fr.) Kuntze - 17; on the resin of Picea abies (MSK-L).

*Scytinium Lichenoides (L.) Otálora, P. M. Jørg. $\&$ Wedin - 29; on the rocks, covered with bryophytes, in the stream of the river (DAU).

*Sclerophora coniophaea (Norman) Mattsson \& Middelb. - 5; on trunks of Quercus robur (MSK-L).

*Sclerophora farinacea (Chevall.) Chevall. - 10; on trunks of Fraxinus excelsior (MSK-L).

SCOLICIOSPORUM SAROTHAMni (Vain.) Vězda - 29; on twigs of Pinus sylvestris (DAU).

*Solorina saccata (L.) Ach. - 26; on sandstone outcrop with cancerous inclusions (DAU).

TONIniopsis subincompta (Nyl.) Kistenich, Timdal, Bendiksby \& S. Ekman - 4; on trunks of Fraxinus excelsior (MSK-L).

TRAPeliopsis fleXuosa (Fr.) Coppins \& P. James 18, 22; on wood of Pinus sylvestris (MSK-L).

*Umbilicaria polyphylla (L.) Baumg. - 29; on rapakivi granite boulder (DAU).

Xanthomendoza fulva (Hoffm.) Søchting, Kärnefelt \& S. Y. Kondr. - 23; on trunks of Tilia cordata (MSK-L).

Xanthomendoza ulophyllodes (Räsänen) Søchting, Kärnefelt \& S. Y. Kondr. - 10; on trunks of Acer platanoides (MSK-L). Sequence ID (GenBank): UDB0799994.

Xanthoparmelia pulla (Ach.) O. Blanco, A. Crespo, Elix, D. Hawksw. \& Lumbsch - 19; on siliceous stones (MSK-L).

\section{ACKNOWLEDGEMENTS}

This work was partially supported by the project 'Preconditions for better biodiversity preservation and ecosystem protection in Latvia' $\mathrm{KF}$ No.5.4.2.1/16/I/001. We are grateful to our reviewers, Inga Jüriado (University of Tartu, Estonia) and David Svoboda (Charles University in Prague, Czech Republic); to Ave Suija (University of Tartu, Estonia) for help with DNA sequence of Xanthomendoza specimens, and to Māris Nitcis (Daugavpils University, Latvia) for the help with map.

\section{REFERENCES}

Andrušaitis, G., Vimba, E. \& Piterāns, A. 1996. Latvian Red Data Book. Rare and extinct plant and animal species. Mushrooms and lichens, 1. Rīga. 202 pp. Anonymous, 1992. Council Directive 92/43/EEC of 21 May 1992 on the conservation of natural habitats and of wild fauna and flora. Current consolidated version: 01/07/2013. https://eur-lex.europa.eu/legalcontent/EN/TXT/?uri=celex\%3A31992L0043. [Accessed: 20.03.2021].

Anonymous, 2000. Rules of Minister Cabinet No. 396. Noteikumi par ipaši aizsargājamo sugu un ierobežoti izmantojamo īpaši aizsargājamo sugu sarakstu (Entry into force: 18.11.2000). https:// likumi.lv/ta/id/12821-noteikumi-par-ipasiaizsargajamo-sugu-un-ierobezoti-izmantojamoipasi-aizsargajamo-sugu-sarakstu. [Accessed: 20.03.2021].

Anonymous, 2013. Rules of Minister Cabinet No. 940. Noteikumi par mikroliegumu izveidošanas un apsaimniekošanas kārtību, to aizsardzību, kā arī mikroliegumu un to buferzonu noteikšanu (Entry into force: 01.01.2013). https://likumi. $\mathrm{lv} / \mathrm{ta} / \mathrm{id} / 253746-$ noteikumi-par-mikroliegumuizveidosanas-un-apsaimniekosanas-kartibu-toaizsardzibu-ka-ari-mikroliegumu-un-to-buferzonunoteiksanu. [Accessed: 20.03.2021].

Anonymous, 2021. NATURA 2000 - STANDARD DATA FORM. Site: LV0200100. https:// natura2000.eea.europa.eu/Natura2000/SDF. aspx?site=LV0200100\#1. [Accessed: 20.03.2021]. Aptroot, A., Czarnota, P., Jüriado, I., Kocourková, J., Kukwa, M., Lõhmus, P., Palice, Z., Randlane, T., Saag., L., Sérusiaux, E., Sipman, H., Sparrius, L. B., Suija, A. \& Thüs, H. 2005. New or interesting lichens and lichenicolous fungi found during 
the 5th IAL Symposium in Estonia. Folia Cryptogamica Estonica 41: 13-22.

Aptroot, A., Sérusiaux, E., Edwards, B. \& Coppins, B. J. 2009. Fellhanera Vězda (1986). - In: Smith C. W., Aptroot A., Coppins B. J., Fletcher A., Gilbert O. L., James P. W. \& Wolseley P. A. (eds): The lichens of Great Britain and Ireland. London. 399 pp.

Auniñš, A., Lārmanis, V., Rove, I., Rūsina, S. \& Laime, B. (eds). 2013. European Union Protected Habitats in Latvia. Interpretation Manual. Riga, Latvian Fund for Nature, Ministry of Environmental Protection and Regional Development. 320 pp.

Brand, M., Coppins, B. J., van den Boom, P. P. G. \& Sérusiaux, E. 2009. Further data on the lichen genus Bacidia s. 1. in the Canary Islands and Western Europe, with descriptions of two new species. Bibliotheca Lichenologica 99: 81-92.

Bruttan, A. 1869. Bericht uber eine lichenologische Excursion in Kur- und Livland. Sitzungsberichte der Naturforscher-Gesellschaft bei der universität Jurjew (Dorpat), 2: 58-62.

Bruttan, A. 1870. Lichenen Est-, Liv- und Kurlands. Dorpat. 166 pp.

Cannon, P., Ertz, D., Frisch, A., Aptroot, A., Chambers, S., Coppins, B., Sanderson, N., Simkin, J. \& Wolselsey, P. 2020. Arthoniales: Arthoniaceae, including the genera Arthonia, Arthothelium, Briancoppinsia, Bryostigma, Coniocarpon, Diarthonis, Inoderma, Naevia, Pachnolepia, Reichlingia, Snippocia, Sporodophoron, Synarthonia and Tylophoron. Revisions of British and Irish Lichens 1: 3-48. https://doi.org/10.34885/173

Coppins, B. J. 1983. A taxonomic study of the lichen genus Micarea in Europe. Bulletin of the British Museum (Natural History). Botany 11(2): 17-214.

Coppins, B. J. 2009. Absconditella Vězda (1965). - In: Smith, C. W., Aptroot, A., Coppins, B. J., Fletcher, A., Gilbert, O. L., James, P. W. \& Wolseley P. A. (eds): The lichens of Great Britain and Ireland. London. Pp. 123-124.

Czarnota, P. 2007. The lichen genus Micarea (Lecanorales, Ascomycota) in Poland. Polish Botanical Studies 23: 1-199.

Ekman, S. 1997. The genus Cliostomum revisited. ACTA UNIVERSITATIS UPSALIENSIS Symbolae Botanicae Upsalienses 32(1):17-28.

Heugel, C. A. 1854. Beitrag zur Kryptogamenkunde der Ostsee-Gouvernements Russland. Korrespondenzblatt des Naturforscher-Vereins zu Riga 6: 7-94.

Heugel, C. A. 1857. Beitrag zur Kryptogamenkunde der Ostsee-Gouvernements Russlands (Nachtrag). Korrespondenzblatt des Naturforscher-Vereins $z u$ Riga 9: 45-49.

Heugel, C. A. 1896. Zur Flechtenflora der Ostseeprovinzen Russland. Korrespondenzblatt des Naturforscher-Vereins zu Riga 17 (9-10): 149-175.

Heugel, C. A. \& Müller, C. J. 1847. Beitrag zur Flora von Livland. Korrespondenzblatt des Naturforscher-Vereins zu Riga 2: 48-50.
Istomina, N. B., Likhacheva, O. V., Stepanchikova, I. S., Kuznetsova, E. S. \& Himelbrant, D. E. 2018. New and rare lichens and allied fungi from the Pskov Region, Russia. Folia Cryptogamica Estonica 55: 21-31. DOI: https://doi.org/10.12697/ fce.2018.55.04

Lucas, C. 1862. Verzeichnis der um Hinzenberg wachsenden Pflanzen. Korrespondenzblatt des Naturforscher-Vereins zu Riga 12: 161-186.

Malta, N. 1925. Latvijas smilšakmens flora. Daba 7: 219-226. (In Latvian).

Mereschkowski, K. S. 1913. Spisok lishainikov Pribaltijskogo kraja. Uchenyje zapiski Kazanskogo Universiteta 30: 1-62. (In Russian).

Motiejūnaitè, J. 2017. Supplemented checklist of lichens and allied fungi of Lithuania. Botanica lithuanica 23(2): 89-106. DOI: https://doi. org/10.1515/botlit-2017-0011

Motiejūnaitè, J., Czyżewska, K. \& Cieśliński, S. 2004. Lichens - indicators of old-growth forests in biocentres of Lithuania and NE Poland. Botanica Lithuanica 10(1): 59-74.

Motiejūnaitè, J., Suija, A., Lõhmus, P., Kuznetsova, E., Tõrra, T., Prigodina-Lukošienè, I. \& Piterans, A. 2006. New or noteworthy lichens, lichenicolous and allied fungi found during the 16th Symposium of Mycologists and Lichenologists in Latvia. Botanica Lithuanica 12(2): 113-119.

Nordin, A., Moberg, R., Tønsberg, T., Vitikainen, O., Dalsätt, Å., Myrdal, M., Snitting, D. \& Ekman, S. 2011. Santesson's checklist of Fennoscandian lichen-forming and lichenicolous fungi. Ver. 29 April 2011. http://130.238.83.220/santesson/ home.php [Accessed 28 Feb 2021].

Orange, A., James, P. W. \& White, F. J. 2001. Microchemical methods for the identification of lichens. British Lichen Society. $101 \mathrm{pp}$.

Pilāts, V. 2007. Biodiversity in Gauja National Park. Sigulda, Gauja National Park Administration, Tech. Rep. 240 pp. (In Latvian, summary in English).

Piterāns, A. 2001. Latvijas ksērpju konspekts. Latvijas veǵetācija 3: 5-46. (In Latvian).

Piterāns, A. \& Leimane, D. 1987. Retās un aizsargājamās ķērpju sugas Gaujas nacionālajā parkā. Mežsaimniecība un mežrūpniecība 4: 10-12. (In Latvian).

Piterāns, A. \& Pokule, A. 1975. Piezīmes par Gaujas nacionāla parka ķērpju floru. Mežsaimniecība un mežrūpniecība 2: 16-17. (In Latvian).

Randlane, T., Saag, A. \& Suija, A. 2019. Lichenized, lichenicolous and allied fungi of Estonia. Ver. December 31, 2019 - http://esamba.bo.bg.ut.ee/ checklist/est/home.php [Accessed: 20.02.2021].

Rodriguez-Rodriguez, D. 2008. The public use in Gauja National Park. Spanish National Research Council (CSIC). 100 pp.

Sérusiaux, E., Coppins, B. J., Diederich, P. \& Scheidegger, C. 2001. Fellhanera gyrophorica, a new European species with conspicuous pycnidia. 
Lichenologist 33(4): 285-289. http://dx.doi. org/10.1006/lich.2001.0328

Simms, M. J. 2016. Cliostomum flavidulum Hafellner \& Kalb. http: / /www.habitas.org.uk/lichenireland/ species.asp?item=500032. [Accessed: 20.02.2021].

Sundin, R. \& Thor, G. 1990. Some lichens from Latvia. Graphis scripta 3: 20-23.

Tibell, L. 1999. Caliciales. Nordic Lichen Flora. V. 1. Bohuslän 5, Uddevalla. Pp. 20-71.

Tønsberg, T. 1992. The sorediate and isidiate, corticolous, crustose lichens in Norway. Sommerfeltia 14: 1-331.
Turlājs, J. 2011. Latvijas geogrāfijas atlants [Geographical atlas of Latvia]. Rīga: Publishing house "Jāña sēta". 43 pp. (In Latvian).

Yatsyna, A. P. 2021. Lichens and related fungi of the reserve "Svislochsko-Berezinsky" (Belarus). Novosti sistematiki nizshikh rastenii 55(1): 215227. (In Russian).

Yatsyna, A. P., Golubkov, V. V., Gimelbrant, D. E., Konoreva, L. A., Kuznetsova, E. S. \& Česnokov, S. V. 2019. Flora Belorusi. Lishajniki, 1. Minsk. 341 pp. (In Russian). 


\section{APPENDIX 1}

\section{List of visited localities in Gauija National Park}

1. Pārgaujas County, Raiskuma Parish, the vicinity of the farms Lejas Sveksi and Kalna Sveki. River Sveksupīte. River bank with Alnus incana (L.) Moench, Prunus padus L., Salix spp. and Frangula alnus Mill., 57.324918 N, 25.178912 E. 11.09.2020, leg. AY.

2. Pārgaujas County, Raiskuma Parish, the vicinity of the farm Kūdums. Open raised bog; the vegetation is composed of Sphagnum mosses, as well as perennial plants - dwarf shrubs (EU habitat 7110), 57.367846 N, 25.147828 E. 11.09.2020, leg. AY.

3. Pārgaujas County, Raiskuma Parish, the vicinity of the farms Lejas Celpi and Kalna Celpi, on the side of the road, 57.352582 N, 25.215449 E. 24.09.2020, leg. AY.

4. Pārgaujas County, Raiskuma Parish, the vicinity of the farm Edernieki, forest compartment 637, forest management unit 24. Tilio-Acerion forest of slopes and ravines. Forest with dominant mixed species composition with Tilia cordata and Acer platanoides, less commonly found trees were Fraxinus excelsior, Quercus robur and Ulmus glabra Huds. (EU habitat 9180*), 57.277644 N, 25.115035 E. 07.09.2020, leg. AY.

5. Pārgaujas County, Raiskuma Parish, the vicinity of the farm Berzini, forest compartment 45, forest management unit 5. Forest with many Quercus robur and Fraxinus excelsior. There were few old trees, among these a solitary old Quercus robur. The undergrowth had many old Corylus avellana (L.) H.Karst., (EU habitat 9160), 57.342519 N, 25.104422 E. 07.09.2020, leg. AY.

6. Pārgaujas County, Raiskuma Parish, the vicinity of the farm Edernieki, forest compartment 638, forest management unit 7. Forest with dominant Populus tremula and Fraxinus excelsior (EU habitat 9180*), 57.280058 N, 25.130352 E. 07.09.2020, leg. AY.

7. Pārgaujas County, Raiskuma Parish, the vicinity of the farm Pielekši, forest compartment 25, forest management unit 2. Old-growth boreal forest (120-140 years) with Picea abies. The ground cover rich in Oxalis acetosella L. (EU habitat 9010*), 57.353857 N, 25.184460 E. 20.09.2020, leg. AY.

8. Pārgaujas County, Raiskuma Parish, the vicinity of the farm Auciems, forest compartment 584 and 586. Bog pine forest with a dense layer of Ledum palustre L. and Vaccinium uliginosum L. in the ground cover (EU habitat 91D0*), 57.353118 N, 25.150779 E. 16.09.2020, leg. AY.

9. Pārgaujas County, Raiskuma Parish, village of Raiskums, Briežu str. A building made of rubble stone around which grow, principally: Fraxinus excelsior and Tilia cordata, 57.312507 N, 25.157114 E. 09.09.2020, leg. AY.

10. Pārgaujas County, Raiskuma Parish, the vicinity of the farms Krastini and Lauras, Ozolu str. An old alley along the road, with Acer platanoides, Fraxinus excelsior, Tilia cordata and Quercus robur, 57.314753 N, 25.150261 E. 09.09.2020, leg. AY.

11. Pārgaujas County, Raiskuma Parish, the vicinity of the farm Pielekši, forest compartment 533. Boreal forest with Pinus sylvestris. The ground cover rich in Oxalis acetosella, (EU habitat 9010*), 57.359443 N, 25.193201 E. 24.09.2020, leg. AY.

12. Pārgaujas County, Raiskuma Parish, village of Ezerkalni, on the side of the road, old Larix spp. alley, 57.306118 N, 25.166060 E. 19.09.2020, leg. AY.

13. Pārgaujas County, Raiskuma Parish, the vicinity of the farm Kalnciemi, forest compartment 546, forest management unit 2, and forest compartment 43, forest management unit 7 . On the border of the forest compartments, in a natural undergrowth of spruce (1-1,7 $\mathrm{m}$ in height), 57.354054 N, 25.203381 E. 24.09.2020, leg. AY.

14. Pārgaujas County, Raiskuma Parish, the vicinity of the farm Edernieki, forest compartment 1, forest management unit 22. Old-growth (160 years) boreal forest with Picea abies, with a large amount of downed coarse woody debris, mainly consisting of spruce logs, (EU habitat 9010*), 57.280641 N, 25.147422 E. 07.09.2020, leg. AY.

15. Pārgaujas County, Raiskuma Parish, the vicinity of the farm Gundegas, forest compartment. 46, forest management unit 5. Boreal forest with Pinus sylvestris. The ground cover rich in Oxalis acetosella. On the shore of Lake Rustegs, (EU habitat 9010*), 57.333748 N, 25.089374 E. 18.09.2020, leg. AY.

16. Pārgaujas County, Raiskuma Parish, the vicinity of the farm Lencu Skola. Road No. V289. Planted birch trees along the road ditch, 57.372323 N, 25.208569 E. 24.09.2020, leg. AY.

17. Pārgaujas County, Raiskuma Parish, the vicinity of the farm Pielekši, forest compartment 43, forest management unit 7 . Boreal forest with Picea abies. The ground cover rich in Vaccinium myrtillus L., (EU habitat 9010*), 57.353667 N, 25.204466 E. 24.09.2020, leg. AY.

18. Pārgaujas County, Raiskuma Parish, the vicinity of the farm Pielekši, forest compartment 561, forest management unit 2. Boreal forest with Pinus sylvestris. The ground cover rich in Vaccinium vitis-idaea L., (EU habitat 9010*), 57.346649 N, 25.224144 E. 22.09.2020, leg. AY. 
19. Pārgaujas County, Raiskuma Parish, the vicinity of the farms Lejas Celpi and Kalna Celpi. On the side of the road. Stones of different sizes collected in groups or scattered, 57.352582 N, 25.215449 E. 24.09.2020, leg. AY.

20. Krimuldas County, Krimulda Parish, surroundings of the city of Turaida. forest compartment 2, forest management unit 3. Boreal forest with Pinus sylvestris, parking area, 57.191060 N, 24.856039 E. 02.09.2020, leg. AY.

21. Krimuldas County, Krimulda Parish, the vicinity of the farm Strautini, forest compartment 1 , forest management unit 6. Forest with Populus tremula and Betula pendula, less common Fraxinus excelsior, Quercus robur, and Alnus incana, (EU habitat 9010*), 57.189381 N, 24.871538 E. 01.09.2020, leg. AY.

22. Krimuldas County, Krimulda Parish, the vicinity of the farm Strautini, forest compartment 56, forest management unit 3. Boreal forest with Pinus sylvestris. The ground cover rich in Vaccinium myrtillus, (EU habitat 9010*), 57.196291 N, 24.862267 E. 01.09.2020, leg. AY.

23. Cèsu County, city of Cesis, park near the railway station, 57.312694 N, 25.281456 E. 14.09.2020, leg. AY.

24. Sigulda County, city of Sigulda, Valley of river Dauda, old boreo-nemoral forest with Picea abies, (EU habitat 9180*), 57.176944 N, 24.889167 E. 03.07.2020, leg. PD \& RM.

25. Cēsu County, Drabešu Parish, Broadleaf forest on slope with Fraxinus excelsior, Quercus robur and Ulmus glabra, (EU habitat 9180*), 57.292847 N, 25.223394 E. 28.08.2020, leg. PD \& RM.

26. Cèsu County, Drabešu Parish, Sandstone outcrop with calcareous inclusions in old coniferous forest, in Roču forest reserve territory, 57.258595 N, 25.117343 E. 28.08.2020. leg. PD \& RM.

27. Castle ruins on the shore of Lake Araišu, 57.250437 N, 25.282715 E. 28.08.2020, leg. PD \& RM.

28. Ungurmuiža manor park. A large number of ancient and veteran trees are present in the park (mostly Quercus robur), 57.362602 N, 25.089561 E. 28.08.2020, leg. PD \& RM.

29. Middle-aged boreal forest, with several veteran trees, dominated by Pinus sylvestris, and small river (Strikupe) crossing forest massive, 57.394742 N, 25.277043 E. 29.09.2020, leg. RM. 